\title{
Implications of diabetes self-management education in metabolic control
}

\author{
Implicaciones de la educación para el autocuidado de la diabetes en el control metabólico
}

Ana L. López-González ${ }^{a}$

\begin{abstract}
:
Diabetes is a chronic, progressive and disabling disease that affects millions of people around the world, with a high mortality rate derived from poor control. The paradigm of the treatment of diabetes has shifted to focus on empowering the person with diabetes to manage the disease successfully and to improve their quality of life. Diabetes self-management education, or its acronym DSME, is a process where people with diabetes gain the knowledge and skills needed to make informed decisions, modify their behavior and to successfully selfmanage the disease and its related conditions, in collaboration with health personnel. To achieve these goals a structured educational program is used in 4 stages which include assessment, planning, implementation, and evaluation. To carry out this program, the model of the seven self-care behaviors known as AADE7 $®$, developed by the American Association of Diabetes Educators, is used as a frame of reference. The objective of this paper is to analyze the components of the education program for diabetes self-care as well as its reference framework, the AADE7@ model, and its importance in the metabolic control of diabetes.
\end{abstract}

Keywords:

Education, self-management, diabetes, metabolic control

\section{Resumen:}

La diabetes es una enfermedad crónica, progresiva e incapacitante que afecta a millones de personas en todo el mundo, con una elevada tasa de mortalidad derivada de un control deficiente. El paradigma del tratamiento de la diabetes ha cambiado para enfocarse en capacitar a las personas que la padecen en el manejo exitoso de la enfermedad y en mejorar su calidad de vida. La educación para el aut ocuidado de la diabetes, o sus siglas EACD, es un proceso mediante el cual las personas adquieren los conocimientos y las habilidades necesarias para tomar decisiones informadas, modificar su comportamiento y para atender, en colaboración con el personal sanitario, satisfactoriamente su enfermedad y sus afecciones relacionadas. Para lograr estos objetivos es utilizado un programa educativo estructurado en 4 etapas que incluyen la valoración, la planificación, la implementación y la evaluación; usando como marco de referencia el modelo de los siete comportamientos de autocuidado conocido como AADE7®, el cual fue desarrollado por la Asociación Americana de Educadores de la Diabetes. El objetivo de este trabajo es analizar los componentes del programa de educación para el autocuidado de la diabetes así como su marco de referencia, el modelo AADE7@, y sus implicaciones en el control metabólico de la diabetes.

\section{Palabras clave:}

Educación, autocuidado, diabetes, control metabólico

\section{INTRODUCTION}

Diabetes represents a public health problem, currently, it is estimated that around 425 million people worldwide, or $8.8 \%$ of adults aged 20 to 79 , suffer from it, and about $79 \%$ live in low and medium income countries. ${ }^{1}$ Diabetes causes disability and death, hitting people at their most productive age and reducing the life expectancy of older people; it also causes impoverishing families, drains national health budgets, slows economic growth, generates catastrophic expenses in vulnerable homes and overload health systems, therefore, early detection and maintaining patients under control rather than a good desire is an urgent need. ${ }^{2}$

In Mexico, statistics show the complexity of the pandemic for a developing country. In 2017, it ranked 5th in the world and this disease represented the 2 nd cause of general mortality in the country. ${ }^{3}$ In addition to data from the National Survey of Health and Nutrition, in 2016, 9.4\% of adults 20 years and older reported a previous medical diagnosis of diabetes, being this prevalence higher in women than in men ( $10.3 \%$ vs $8.4 \%$, respectively). ${ }^{4}$

a Correspondence author, Asociación Mexicana de Diabetes en la Ciudad de México, A.C., ORCID: 0000-0002-1953-0189, Email: laulopg99@gmail.com 
Diabetes is a chronic-degenerative and multicausal disease, closely related to the growth and aging of the population, increased obesity, eating disorders and sedentary lifestyles. ${ }^{3}$ It is characterized by chronic hyperglycemia resulting from defects in the secretion or action of insulin, which leads to alterations in the metabolism of the macronutrients and, in the long term, damage and failure of several organs, especially the eyes, kidneys, nerves, heart, and blood vessels; its complications are the main cause of blindness, terminal chronic renal failure and non-traumatic amputation in adults. ${ }^{5}$

Diabetes classified into the following categories:

- Type 1 diabetes. Destruction of pancreatic beta cells.

- Type 2 diabetes. Progressive defect in the secretion of insulin, resistance to insulin.

- Gestational diabetes. It diagnosed in the second or third trimester of pregnancy.

- Other specific types of diabetes. A consequence of various causes such as genetic alterations in beta cell function, genetic defects in insulin function, diseases of the exocrine pancreas, diabetes induced by drugs or chemicals. ${ }^{6}$

The diagnosis agrees with the criteria established by the American Diabetes Association (ADA), as shown in Table 1.

\section{Table 1. Diagnosis criteria of diabetes}

\begin{tabular}{l|l}
\hline Criteria & \multicolumn{1}{l}{ Reference value } \\
\hline $\begin{array}{l}\text { Fasting Plasma Glucose (fasting } \\
\text { at least 8 hours) }\end{array}$ & $\geq 126 \mathrm{mg} / \mathrm{dL}$. \\
\hline $\begin{array}{l}\text { 2-h plasma glucose (2-h PG) value } \\
\text { during a 75-g oral glucose } \\
\text { tolerance test (OGTT) }\end{array}$ & $\geq 200 \mathrm{mg} / \mathrm{dL}$. \\
\hline $\begin{array}{l}\text { Glycated hemoglobin (A1C } \\
\text { criteria) }\end{array}$ & $\geq 6.5 \%$ \\
\hline $\begin{array}{l}\text { Casual glucose. } \\
\text { (1) classic symptoms of } \\
\text { clear } \\
\text { hyperglycemia (polyuria, } \\
\text { polyphagia, polydipsia). }\end{array}$ \\
\hline
\end{tabular}

Source: Own elaboration from the Standards of medical care in diabetes, 2019 by the American Diabetes Association. ${ }^{5}$

The underlying principle in the management of diabetes has undergone several important changes in the last two decades. At one time, it thought to be a disease with which micro and macrovascular complications would inevitably develop. However, current approaches to management recognize the benefit of maintaining strict control of blood glucose and addressing associated metabolic disorders. ${ }^{7}$ Also, it has been proved that when patients can express their points of view, problems or concerns, and make consensual decisions with health personnel, they are more likely to be involved, and take greater responsibility in their health care. ${ }^{2}$
To achieve adequate metabolic control, people living with diabetes must perform a series of daily care routines that depend directly on their commitment and responsibility with the disease. Nevertheless, basic knowledge and the necessary motivation are not always available to carry out these self-care behaviors. ${ }^{8,9}$ Selfcare refers to the actions that people adopt for the benefit of their own health, without formal medical supervision. The role of the active patient provides a double benefit: it acquires autonomy with respect to the system and, in turn, helps to reduce unnecessary demand on the health system. ${ }^{10,11}$

The American Association of Diabetes Educators (AADE) has adopted the Diabetes Self-Management Education (DSME) model as a methodology for patient-centered diabetes caretaking as a reference the AADE7® model, which mentions seven healthy behaviors for self-care of diabetes. ${ }^{12}$ The objective of this work is to analyze this methodology and its implications in the metabolic control of diabetes.

\section{HISTORY OF DIABETES EDUCATION}

In 1914, the importance of diabetes education in developed countries began to glimpsed; with Dr. Elliot P. Joslin, emphasizing the training of nurses specialized in education. He was a firm believer in the importance of patient education. $\mathrm{He}$ believed in empowering patients to care for their own diabetes. He often remarked, "Teaching is cheaper than nursing" reflecting the importance he placed on patients handling their self-care and preventing problems instead of paying for costly medical treatment. $^{13}$

In 1936, with the arrival of insulin, counseling in clinical care was a great contribution for people with type 1 diabetes, as they delivered education in schools, homes, and families of these young people, diabetic care nurses expanded to teach patients in addition to do the carbohydrate count. In the decade of the forties, diabetic education was already being taught in the United Kingdom. ${ }^{14}$ In the $50 \mathrm{~s}$, the appearance and increase of type 2 diabetes and the evolution of oral hypoglycemic drugs required specific educational goals and better control for patients. In the '70s, formal education for diabetes educators was incorporated. ${ }^{15}$

The publication of the studies UKPDS (UK Prospective Diabetes Study) and DCCT (Diabetes and Control Diabetes Trial) in the ' 90 s, changed the focus of the care of patients with diabetes, demonstrating the need and benefit of intensified treatments, which made charge diabetes education very important. ${ }^{16}$ 


\section{DIABETES SELF-MANAGEMENT EDUCATION}

Accordance with the National Diabetes Education Standards, Diabetes Self-Management Education (DSME) is defined as "the process of facilitating the acquisition of knowledge, skills, and abilities necessary for informed decision-making, and selfmanagement of diabetes", by modifying inappropriate behaviors for this purpose. ${ }^{17}$ Traditionally, the training given by professionals was aimed at knowing how to carry out the prescribed treatment and address the symptoms of the disease. Different pedagogical studies have shown that this method is not enough for the person to change their health behavior and that improving these results related to the educational methodology used. ${ }^{16}$

Etymologically, education means driving, but this meaning is dangerous because it implies the idea that learners are mere passive instruments without autonomy or decision-making capacity. The problem is that in the classic concept, the student and the patient were considered ignorant, whose only obligation was obeying and be passively driven. This vertical educational structure of the mandate and obedience has changed little by little for a more horizontal structure in which it tried to respect as far as possible the autonomy of the apprentice and the educator. ${ }^{18}$

The patient must be seen as a person with making decision capacity, who goes to the doctor because he or she needs help to improve their health status, as health professionals have the knowledge and skills that can be beneficial for the patient. ${ }^{19}$ Transmitting information by itself does not develop a changed behavior or create skills, the information must be applied and the skills practiced so they are incorporated as part of the daily routine..$^{20,21}$

Diabetes education depends on biomedical advances, new treatments and technologies developed at each moment, and the sciences and educational techniques to know when and how to educate ${ }^{16}$ One of the central aspects in the educational activity is to promote changes in behavior. To achieve this, it is required to know about the methods or models to help patients to become active and make changes in their self-care behaviors. ${ }^{22}$ Participatory methodologies favor the acquisition of greater degrees of personal autonomy. ${ }^{10}$ Patient participation means involvement of the patient in decision making or expressing opinions about different treatment methods, which includes sharing information, feelings, and signs and accepting health team instructions. ${ }^{11,23}$

Education programs should be designed according to the patient's health beliefs, cultural needs, current knowledge, physical limitations, emotional concerns, family support, financial status, medical history, literacy and other factors that influence the ability of each person to meet the challenges of self-care, not an easy task. ${ }^{24}$ The $95 \%$ of the success of diabetes treatment depends on self-care, so educating for self-care becomes the cheapest therapeutic resource in the short, medium and long term, the most effective and without side effects. ${ }^{22}$

\section{EDUCATION AS A CONTINUOUS PROCESS}

The intervention or educational program is the most important tool for the educator; it is the instrument that allows systematizing the actions and establishes the objectives. ${ }^{25}$ The diabetes education program must be structured in 4 main phases and considered as a continuous process, like seen in Figure 1, taking into account that the needs of patients change over time and that this cycle will be renewed as many times as it takes. ${ }^{14}$

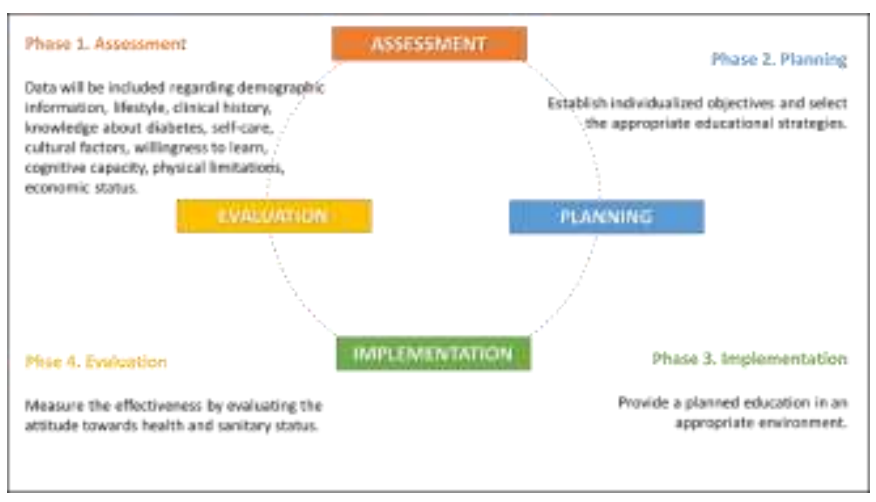

Figure 1. Process of Diabetes Self-Management Education. ${ }^{14}$

\section{Assessment}

Corresponds to the beginning of the educational program, this will provide us with relevant information to assess the educational needs of the patient. A questionnaire can be applied to allow us know the demographic data, routine work and study, health status, previous knowledge, self-care skills, physical and cognitive limitations, cultures and beliefs. It is also very important to evaluate the environment in which the patient inserted his family and support networks, which will influence in a positive or sometimes negative way in his or her educational and self-care process. ${ }^{25}$

The educator must practice active listening, eye contact and observation skills to create an environment in which the patient feels that their needs are taken into account. The record of the information must be objective and as the patient refers. After this stage, it is possible to have an educational diagnosis of the patient. $^{26}$ 


\section{Planning}

This part of the process is where the objectives are established. These must be reasonable, concrete and measurable; there must be a mutual agreement between the patient and the educator regarding the fulfillment of the objective. These objectives should raise from the person with diabetes, for example: "I will take my blood sugar every day until the new control". There are different learning methodologies, but these must be adapted to the needs of each patient. They can be sessions of individual talks, problem solving and role-playing. ${ }^{27}$

Depending on the time available and how much can be taught, it is necessary to prioritize the objectives, there are some aspects that must be taught immediately for safety reasons (for example identification and treatment of hypoglycemia), and other more advanced ones that can be taught later. ${ }^{18}$

\section{Implementation}

In this third phase of the educational process, the teachinglearning process is put into practice, the place where the education will take place can be any place, just making sure that the environment favors the exchange of information with the minimum of distraction. During the performance of the educational activity, it should be tried to always explain the simplest to the most complex, use direct and clear language and reinforce the information delivered at the end of education, corroborating the understanding it. It is important to use teaching materials to promote learning. ${ }^{25,27}$

\section{Evaluation}

This stage must be planned and carried out at all times. In general, it is recommended to carry out a planned evaluation at 3 and 6 months, where aspects such as improvement in biomedical parameters (glycosylated hemoglobin, blood pressure values, among others) will be evaluated, as well as psychosocial aspects such as quality of life, well-being and self-care. It is very important to make positive reinforcements against the achievements and improvements of previously stated objectives. ${ }^{14}$

With the systematic collection of information about the activities, characteristics and results of the program, judgments can be made about the effectiveness and capacity of the patient to make informed decisions and above all their willingness to change behaviors. Also, throughout the educational process, it is established a series of expected results in a logical and gradually sequence, as it can be observed in Figure 2. ${ }^{28}$
The behavior has been defined as the primary outcome of diabetes education (with behavior change being the primary measurement) because in the care of chronic disease, it is the key element in attaining or maintaining desired levels of clinical parameters and also improve health-related outcomes. ${ }^{28}$

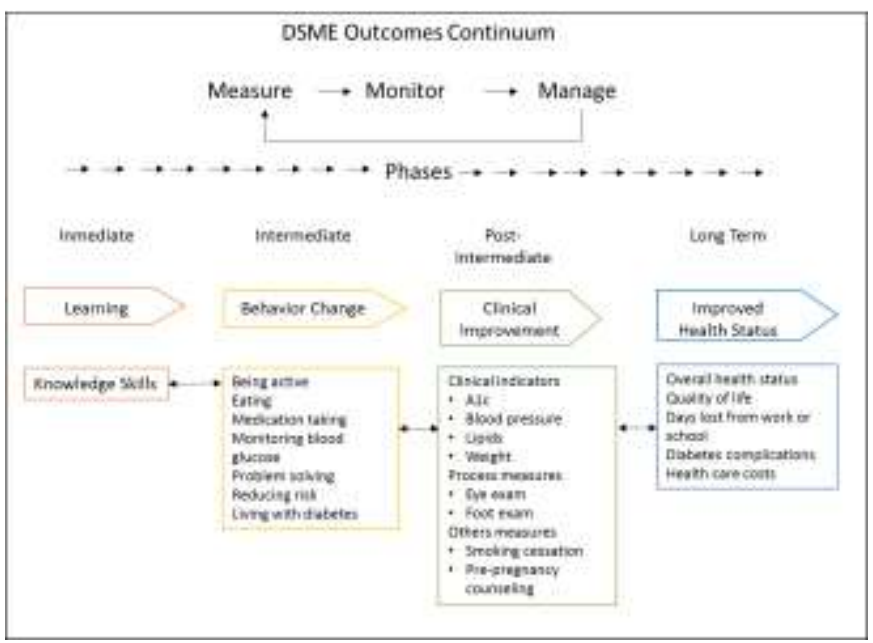

Figure 2. Expected results of the education process for diabetes self-care. ${ }^{24}$

Knowledge and skills are important only to the extent that they facilitate appropriate self-care activities. The self-care activities of the AADE7 ${ }^{\circledR}$ program, in turn, are important only insofar as they facilitate the improvement of clinical and health-related outcomes. $^{26}$

\section{AADE7 $®$ PROGRAM}

In 1997, the AADE, developed the Diabetes Self-care Education model (DSME or EACD, for its acronym in Spanish), this is based on the teaching of 7 self-care behaviors, represented in Table 2, a method that is known as AADE7®. ${ }^{29}$

Table 2. The 7 behaviors for diabetes self-care.

\begin{tabular}{l}
\hline Self-care behaviors \\
\hline 1. Healthy eating \\
\hline 2. Being active \\
\hline 3. Monitoring \\
\hline 4. Taking medication \\
\hline 5. Problem solving \\
\hline 6. Reducing risks \\
\hline 7. Healthy coping \\
\hline
\end{tabular}

Source: Own elaboration from Galindo and collaborators. ${ }^{16}$

The AADE7® program as part of the DSME provides a standardized nomenclature for the evaluation, identification and resolution of barriers, the establishment of objectives, documentation, and measurement, improvement of quality and 
formulation of policies. The standardized nomenclature provides diabetes education with greater coherence and improves the quality of care provided to people with diabetes. ${ }^{28}$ Supports a paradigm shift in diabetes education from a content-based practice to a results-oriented practice. ${ }^{16}$ The objective is to accompany the person so that they voluntarily change their behavior and are willing to acquire new skills, abilities and attitudes in 7 dimensions of self-care to direct their treatment with an optimum quality of life. ${ }^{29}$

\section{Healthy eating}

There is evidence that shows the benefits of a healthy eating for people with diabetes. These include improvement in glycemic control and lipid profile, maintenance of blood pressure in a target range and weight loss or maintenance. ${ }^{30}$ Because there is no set of nutrition recommendations or intervention that applies to all persons with diabetes, the AADE believes nutrition and education should begin with an assessment of each individual's current eating habits and preferences. Then, in collaboration with the individual, the appropriate nutrition education program and goals should be determined. ${ }^{31}$

Healthy eating represents a complex set of behaviors such as making decisions several times a day about what to eat, when to eat and how much to eat; be influenced by family patterns, habits, preferences, availability of food, emotional state and glycemic control. ${ }^{18}$ Basic information includes: the food groups, foods that increase the glycaemia, size of the portions, carbohydrate content in each group, way of exchanging or equating the food, the convenient time for meals, glucose monitoring and how to use the records obtained from it, prevention, identification and management of a hypoglycemia, the relationship between food, physical activity and medication. ${ }^{30}$

\section{Being active}

Going back and staying physically active refers to the act of spending energy, the benefits of exercise are among others, improving glycemic control, reducing stress, improving body mass index and weight loss and helping control lipids. ${ }^{25}$ Before starting, a medical evaluation recommended to identify neurological or vascular complications that may be aggravated by exercise. An exercise test should be included in the specific case of patients who have additional risk factors for cerebral vascular disease, presence of peripheral vascular disease or autonomic neuropathy, who are older than 35 years or older than 25 years old but who live with type 2 diabetes of more than 10 years of evolution. $^{32}$
The evaluation of the patient must also identify their needs, weight control, glycaemia, as well as the provision and the presence of contraindications, risks and limitations, barriers to exercise. The design of an exercise plan should include the components of the exercise, such as the type, intensity, duration and frequency of your practice, as well as establishing the heating and cooling. Regarding educational goals, the patient must support to increase physical activity constantly, achieving 20 to 30 minutes of low to moderate intensity exercise performed 3 to 5 times a week, based on the goals set by the patient establish. ${ }^{33}$

\section{Monitoring}

Self-monitoring may include such assessments as blood glucose levels, blood pressure, foot checks, steps walked, measurement of glycosylated hemoglobin, ketone bodies and weight. All of them are necessary activities to keep an adequate control and to have knowledge of the current state of the disease..$^{33,34}$

Self-monitoring behaviors aim to prevent or slow the progression of diabetes complications. Self-monitoring of capillary glucose is a tool that guides glycemic management strategies and has the potential to improve the problem-solving and decision-making skills of people with diabetes and their health care providers, promotes improved understanding of the impact of food, physical activity and medications on blood glucose levels. It can facilitate, more timely, the adjustment of therapeutic regimens and support flexibility in meal planning, physical activity and medication administration. $^{18}$

Involves explaining the patient how to measure capillary blood glucose by electronic devices at different times of the day. It is based on making informed decisions, but for this, it is necessary that the patient acquire a combination of technical and cognitive skills as well as the ability to interpret the results obtained from the measurement to evaluate the therapeutic response and the achievement of the glycemic objectives. Some of the minimum knowledge to implement this behavior are, knowing the glycemic objectives, testing scheme, as well as waste management, how to keep an adequate record of results, most importantly, learn to interpret and use these results. ${ }^{34}$

\section{Taking medication}

The value of pharmacologic therapy in achieving and maintaining diabetes control has been clearly established. Among patients who require pharmacological therapy, adherence is essential for the optimal diabetes outcomes and control. The worst results of diabetic care are linked to poor adherence to diabetes medications. The most commonly cited factors for nonadherence to medication 
therapy include regimen complexity (need to split tablets, mix products), dosing frequency greater than twice daily, cost, lack of self-confidence, lack of education about the use of the product, depression, and presence or fear of adverse effects. ${ }^{35}$

Diabetes educators are in a key position to promote medication taking by (1) identifying potential barriers to medication adherence, (2) facilitating strategies to overcome barriers, and (3) providing follow-up assessment to ensure the ongoing medication-taking ability for patients. ${ }^{31}$ This behavior also requires the combination of knowledge and skills in the taking of oral or injected medications, considering the periodicity and the technical ability to do so. The patient must be fully aware of his medication, how it is called, when should be taken or applied, how and where to store it, what to do in case of trips or outings, as well as the secondary effects derived from its consumption and the manner of control them or avoid them. ${ }^{25,33}$

\section{Problem solving}

It focuses mainly on the acute complications of diabetes, it is about providing the knowledge and skills to recognize and respond to situations not anticipated in episodes of hyperglycemia, hypoglycemia and days of illness, both in identifying symptoms, treatment guidelines and strategies of prevention. $^{18}$

The skills to solve problems are the most complex to teach and the least easy to learn. A systematic review of problem solving in diabetes highlighted the complexity of this behavior, noting that it is a multidimensional concept. In fact, few studies have included general problem-solving measures as part of diabetes education interventions. ${ }^{27}$ However, several studies, including one by Glasgow and colleagues, associate low levels of problem solving with poor glycemic outcomes. ${ }^{31,36}$

More studies are needed to elucidate the mechanisms of action and the optimal approaches to standardize evaluation and intervention. The barriers, as in the other behaviors, are usually cognitive, financial, emotional or physical, as well as the lack of coping strategies. Immediate educational goals include defining personal glycemic goals, identifying causes, symptoms and signs of hypo and hyperglycemia as well as their management and prevention, regarding days of illness, defining causes, measuring blood glucose and ketones, and establishing their management. ${ }^{31}$ Because the patient is the expert in his life and in his diabetes, it is recommended that they establish the course of action for the solution of a given problem, respecting their preferences, lifestyle and personal goals, all of this while learning from experience what works and what does not work. ${ }^{33}$

\section{Reducing risks}

Risk reduction is defined as the implementation of effective behaviors to prevent or slow the progression of chronic complications of diabetes. To achieve this goal, the standards of care established by the ADA are followed in clinical conditions such as overweight, obesity, hypertension, smoking, foot care, some indicators of metabolic control such as glycaemia, lipids, urine albumin for example. As well as the assessment of the interventions of other professionals in the management of the patient, such as ophthalmologist, nephrologist, cardiologist, etc. ${ }^{27}$

Diabetes care processes and outcomes have improved over the past 10 years, but in one study, only approximately $7 \%$ of persons with diabetes have achieved established goals for glycemic control, blood pressure, and lipids. ${ }^{22}$ The frequency of these standards carried out depending on the situation. Patients must know the therapeutic goals and the support provided by health services. The barriers experienced by the patient are diverse, including financial, time, travel, physical disabilities, distrust of their doctors, and one of the most important, ignorance about the evolution and severity of the disease. ${ }^{31}$

\section{Healthy coping}

Refers to a psychosocial adaptation, to all aspects of living with diabetes, what people do to face the disease, how they perceive their situation and their relationship with other people. ${ }^{25}$ The patient must know and recognize that everyone has problems, the benefits of treatment and self-care and the fact that motivation is an internal function. The barriers to which the patient faces many times are the lack of knowledge, the financial ones, in many cases the lack of support and in most cases, the psychological stress due to the situations they are living. Changes in behaviors depend on the intentions, motivation and abilities of the patient to solve their problems. ${ }^{31}$

When barriers seem insurmountable, good intentions alone cannot sustain behavior. Coping efforts can become difficult and, in turn, a person's ability to self-care can deteriorate. ${ }^{27} \mathrm{~A}$ systematic review of the literature on coping, negative emotions, and diabetes management by Fisher and colleagues identified a number of well-controlled studies that evaluated cognitive-behavioral treatment of depression, coping/problem-solving interventions, support groups, and cognitive analytical therapy. ${ }^{37}$

An important part of the diabetes educator's work is identifying (1) the patient's thoughts regarding living with diabetes, (2) the patient's motivation to change behavior, (3) the presence and 
intensity of negative emotions, and (4) the social/situational barriers and facilitators of optimal self-care. ${ }^{31}$

The 7 self-care behaviors are essential for successful and effective self-control, they provide a reference framework based on evidence for the assessment, planning, implementation and evaluation of the educational program. ${ }^{28}$

\section{IMPLICATIONS OF THE DSME IN THE METABOLIC CONTROL}

Diabetes is not curable, although a degree of control can be achieved in which it can be difficult to find signs of the disease. The aim of the treatment is to avoid complications and sequelae, and this is better when strict control is achieved. Proper metabolic control is one of the main goals of diabetes education. ${ }^{18}$ The ADA has published control goals for proper diabetes management based on clinical evidence and recommendations from the National Diabetes Education Program and Diabetes Quality Improvement Project: Glycosylated hemoglobin $<7.0 \%$, preprandial glucose between $80-130 \mathrm{mg} / \mathrm{dL}$, postprandial glucose $<180 \mathrm{mg} / \mathrm{dL}$, blood pressure $<130 / 80 \mathrm{mmHg}$ and LDL cholesterol $<100 \mathrm{mg} / \mathrm{dl} .{ }^{38}$

Comprehensive treatment of individuals with diabetes should include not only pharmacological treatment; to achieve the goals of control, the education that the patient receives, the commitment and the motivation that turns out to be essential for the therapeutic measures. $^{24}$

In 2015, Galindo Rubio and colleagues developed a study whose objective was to analyze the results of the Diabetes, Attitudes, Wishes and Needs 2 study (DAWN2) on self-care habits and participation in therapeutic education activities in Spain. The DAWN2 study (an international, cross-sectional observational study) helps to clarify what are the barriers and unmet needs with respect to self-care and the therapeutic education offer available for patients and their families. ${ }^{2,39}$

It reported that only $46 \%$ of people with type 1 diabetes and $39 \%$ of people with type 2 diabetes have self-care skills. In addition, only $48.8 \%$ of the subjects had participated in an educational program. They concluded that all people with diabetes should acquire the knowledge, skills and attitudes necessary for self-care to be part of their daily routine. ${ }^{39}$

Other studies mention the following barriers for patients: lack of interest, the perception that they do not need it, transportation problems, rejection of group sessions, education programs at inconvenient times and lack of time. ${ }^{35}$
In a meta-analysis of 162 randomized controlled trials, Tricco, et $a l$, evaluated the key strategies needed to improve the quality of care in diabetes, and established that strategies to promote selfcare and education for patients with diabetes result in improved control of diabetes the glycosylated hemoglobin. ${ }^{40}$

Norris, et al, reviewed 72 studies that evaluated the effect of education on self-care, reported a positive impact with respect to knowledge of diabetes, self-monitoring of capillary glucose, dietary habits and in short-term glycemic control ( $<6$ months). The effect of the interventions on the lipid profile, physical activity, weight and blood pressure was variable. Sometimes, in long-term studies, there was improvement in glycemic control. The authors concluded that interventions that involved active participation of the patient were better with respect to glycemic control, weight and lipid profile. ${ }^{41}$

In Mexico, Compeán Ortiz, and colleagues conducted a descriptive and correlational study that aimed to analyze self-care behaviors (diet, exercise, monitoring and medication) and its relationship with glycemic control, lipid profile, body mass index (BMI), waist circumference and percentage of body fat, in a random sample of 98 adults with type 2 diabetes in a peripheral area of the city of Nuevo León; between 2005 and 2006. The results showed a low self-care index (average $=36.94$ ). It was found significant correlation between self-care and glycosylated hemoglobin, HbA1c ( $\mathrm{p}<0.001)$, triglycerides $(\mathrm{p}=0.040)$, body mass index $(p=0.014)$ and body fat percentage $(p=0.029)$. They indicate the need to rethink the contents and strategies of teaching implemented by health professionals in the education of patients with diabetes. ${ }^{42}$

There is a wide range of educational interventions aimed at people with diabetes. However, a high percentage of these interventions delivered empirically, without a methodology or conceptual reference model.,22 According to Burke and collaborators, education programs designed in accordance with AADE guidelines based on the "seven self-care behaviors"; showed a reduction in hemoglobin from $8.39 \pm 0.03$ to $7.16 \pm 0.67$ for people who completed the program, this reduction of $1.23 \%(\mathrm{P}=$ $0.0000)$ in the A $1 \mathrm{C}$ is statistically and clinically significant ${ }^{27}$

In 2016, Martínez-Castañed a and collaborators conducted a quasiexperimental study for people with type 2 diabetes, in which they implemented an educational program structured in international guidelines and based on the methodology of the 7 self-care behaviors (AADE7 $®$ ), the patients presented a decrease of $1.05 \%$ in the glycosylated hemoglobin; statistically significant, which helped lower the risk of developing acute and chronic complications. ${ }^{24,29}$ 
Diabetes self-care education programs that have achieved recognition (through the American Diabetes Association) or accreditation (through the American Association of Diabetes Educators) and that are designed and delivered in accordance with national established stand ard s can be provided in several ways and by various providers, as long as the providers are sufficiently trained and supervised. ${ }^{27}$

In 2004, Abbate wrote, "improving diabetes care requires competent providers". ${ }^{43}$ In Mexico, there are several institutions responsible for educating diabetes educators, and a certification system for diabetes educators coexists (evaluated every 5 years) managed by the "Consejo Nacional de Educadores en Diabetes" (CONED), whose role is to maintain standards minimums of diabetes education to improve the quality of professional practice of educators. ${ }^{18}$

The certification process involves an evaluation by the council followed by a practical test where advisors analyze the information provided and check if it meets the required standards, methodology originated in the DSME program and the AADE7® model. ${ }^{44}$

\section{CONCLUSIONS}

To ensure good control of diabetes, it is necessary to strengthen the sense of co-responsibility in all actions, programs, and public policies. The natural history of diabetes can be modified with actions that change its clinical course. Generation of values and the empowerment of the subjects should replace education based on the distribution of information. The methodology used by international organizations, such as the self-care behaviors of the AADE7 $®$, represents an element that is being underutilized and has been demonstrated that has clear improvements in the metabolic control of the disease and therefore an opportunity to reduce the incidence of complications, improve the quality of life of patients and thereby prevent their disability and premature death, also allowing for comparative evaluations, standards and measure universally the effects of educators and the DSME.

\section{REFERENCES}

1. Han Cho N, Kirigia J, Mbanya JC, Ogurstova K, Guariguata L, Rathman W, et al. Diabetes por regiones. In: Karuranga S, da Rocha Fernandes J, Huang Y, Malanda B, editors. Diabetes Atlas de la FID. 8th ed; 2017: 4065 .

2. Hernández Jiménez S, Hernández Ávila M, Hernández Ávila JE. La educación en diabetes. In: Aguilar Salinas C, editor. Acciones para enfrentar a la diabetes. Documento de postura. 1st ed. México: ANM; 2015: 351-392.
3. Hernández-Ávila M, Gutiérrez JP, Reynoso-Noverón N. Diabetes mellitus en México. El estado de la epidemia. Salud Publica Mex. 2013; 55(sup12): S129-S136.

4. Instituto Nacional de Salud Pública. Encuesta Nacional de Salud y Nutrición de Medio Camino 2016. [Document on the Internet]. 2018. [Updated October 31, 2016; cited 4 Feb 2018]. Available from: https://www.gob.mx/cms/uploads/attachment/file/209093/ENSANUT.pdf

5. American Diabetes Association. Classification and Diagnosis of Diabetes: Standars of MedicalCare in Diabetes - 2019. Diabetes Care. 2019; 42(supl 1): $\mathrm{S} 13-\mathrm{S} 28$

6. Secretaría de Salud. NOM-015-SSA2-2010, Para la prevención, tratamiento y control de la diabetes mellitus. [Document on the Internet]. 2018. [Updated January 18, 2001; cited 4 Feb 2018]. Available from: http://www.salud.gob.mx/unidades/cdi/nom/015ssa24.html

7. Mazze RS, Strock ES, Simonson GD, Bergenstal RM. Introduction to Staged Diabetes Management. In: Matrex editor. A Systematic Approach. 2nd ed. England; 2006: 3-23.

8. Bolaños E, Sarría-Santamera A. Perspectiva de los pacientes sobre la diabetes tipo 2 y relación con los profesionales sanitarios de atención primaria: un estudio cualitativo. Aten. Primaria. 2003; 32(4): 195-202.

9. López López E, Ortiz Gress AA, López CarbajalMJ. Intervención educativa sobre el nivel de conocimientos en pacientes con diabetes y baja o nula escolaridad. Inv. Ed. Med. 2016; 5(17): 11-16.

10. Romero Baquedano I, dos Santos MA, Martins TA, Zanetti ML. Autocuidado de personas con Diabetes Mellitus atendidas en un servicio de urgencia en México. Rev. Latino-Am. Enfermagem. 2010; 18(6): 1-10.

11. Lerman I, López-Ponce A, Villa RA, Escobedo M, Caballero EA, Velasco ML, et al. Estudio piloto de dos diferentes estrategias para reforzar conductas de autocuidado y a dherencia al tra tamiento en pacientes de bajos recursos económicos con diabetes tipo 2. Gac. Méd. Méx. 2009; 145(1): $15-19$.

12. Vargas Santillán ML, Rodríguez García C, Amador Velázquez R, Oviedo Zúñiga AM, García Lavalley FJ, Mendieta Vargas A. Estudio comparativo en dos grupos de pacientes con Diabetes Mellitus tipo 2 que se someten a una intervención educativa de autocuidado en el instituto de salud del estado de México. Waxapa. 2012; 1(6): 50-56.

13. Joslin Diabetes Center. From "Wandering Nurse" to Certified Diabetes Educator. [Document on the Internet]. 2019. [Updated 2019; cited 24 March 2019]. Available from: https://www.joslin.org/about/from_wandering_nurse_to_certified_diabete s_educator.html

14. Hevia VP. Educación en diabetes. Rev. Med. Clin. Condes. 2016; 27(2): 271-276.

15. Allen NA. The History of Diabetes Nursing, 1914-1936. Diabetes Educ 2003;29(6): 976-989.

16. Galindo Rubio M. Educación terapéutica básica. Diabetes Prá ctica. 2016; 07(supl 4): S1-S56.

17. Pichardo-Hernández JH, Elizaldi-Lozano NE. Alcances de una estrategia educativa en pacientes diabéticos de una unidad de medicina familiar. Aten. Fam. 2015;22(4): 108-110.

18. Pérez-Pasten E, Bonilla-Islas A. Diseño del programa educativo. In: PérezPasten E, editor. Educa ción en diabetes, manual de a poyo. 2nd ed. México: AMD; 2015: 113-158.

19. Vera Delga do A. Humanismo y medicina. Algunas reflexiones pertinentes. Acta Med. Colomb. 2004;29(4): 297-301.

20. Chacón Pizano WL, Mejía Rodríguez O, Paredes Saralegui JG, Gómez Alonso C. Impacto de una intervención educativa prevenimss en el estilo de vida en hombres de 20 a 59 años. Aten. Fam. 2012;19(3): 53-57. 
21. Carrasco E, Flores G, Gálvez C, Miranda D, Pérez ML, Rojas G. El autocontrol de la diabetes. In: Flip-Axis ltda, editors. Manual para educadores en diabetes mellitus. 1st ed. Santiago, Chile; 2007: 19-32.

22. Chrvala CA, Sherr D, Lipman RD. Diabetes self-management education for adults with type 2 diabetes mellitus: A systematic review of the effect on glycemic control. Patient Educ. Couns. 2016;99(6): 926-943.

23. Vahdat S, Hamzehgardeshi L, Hessam S, Hamzehgardeshi Z. Patient Involvement in Health Care Decision Making: A Review. Iran. Red. Crescent. Med. J. 2014; 16(1): e12454.

24. Powers MA, Bardsley J, Cypress M, Duker P, Funnell MM, Fischl AH, et al. Diabetes Self-management Education and Support in Type 2 Diabetes. A Joint Position Statement of the American Diabetes Association, the American Association of Diabetes Educators, and the Academy of Nutrition and Dietetics. J. Acad. Nutr. Diet. 2015; 115(8): 1323-1334.

25. Centro de Orientación Alimentaria. Revisión científica sobre educación en diabetes. [Document on the Internet]. 2015. [Updated 2015; cited 4 Feb 2019]. Available from: http://www.coanutricion.com/argumentaciones/ArgumentacionTecnica_EenD.pdf

26. American Association of Diabetes Educators. AADE7TM Self-Care Behaviors. AADE Position Statement. [Document on the Internet]. 2014. [Updated December 03, 2014; cited 4 Feb 2019]. Available from: https://www.diabeteseducator.org/docs/default-source/legacydocs/_resources/pdf/publications/aade7_position_statement_final.pdf?sfv $\operatorname{rsn}=4$

27. Burke SD, Sherr D, Lipman RD. Partnering with diabetes educators to improve patient outcomes. Diabetes Metab. Syndr. Obes. 2014; 7: 45-53.

28. American Association of Diabetes Educators. AADE Position Statement. AADE7 $^{\mathrm{TM}}$ Self-Care Behaviors. Diabetes Educ. 2008; 34(3): 445-449.

29. Martínez-Castañeda D, Mota-Sanhua V, Olmos-Bringas M, JácomeMondra gón JA, Moreno-Mendoza BR, Pérez-Rosas P, et al. Modificación de indicadores clínicos en pacientes con prediabetes o Diabetes Mellitus tipo 2 por medio de un programa educativo. Aten. Fam. 2016; 23(3): 8994.

30. Álvarez Martínez EM. Herramientas para la educación alimentaria. In: Alfil, editors. Manual de nutrición en diabetes para profesionales de la salud. 1st ed. México; 2012: 157-167.

31. American Association of Diabetes Educators. Guidelines for the Practice of Diabetes Self-Management Education and Training (DSME/T). Diabetes Educ. 2009; 35(supl 3): S85-S107.

32. Yépez A, Velasco ML, Ramírez C, Cuevas D, Almeda Valdés P, Joya J, et al. Guías prácticas para el uso de la insulina. Sociedad Mexicana de Nutrición y Endocrinología. [Document on Internet]. 2009. [Updated Jul 01, 2009; cited 8 Feb 2019]. Available from: http://www.cmon.mx/autoadministrable/diplomadousers/modulos/Guias $\% 20$ practicas $\% 20$ para\%20el\%20uso \%20de\%20insulina.pdf

33. Federación Mexicana de Diabetes. Los 7 comportamientos. Diplomado de educadores en diabetes en línea en México. [Document on Internet]. 2008. [Updated 2008; cited 14 Feb 2019]. Available from: fmdiabetes.org/los-7comportamientos-para-el-autocuidado-en-diabetes/

34. Gagliardino JJ, Turatti L, Davidson JA, Rosas Guzmán J, Castañeda Limones R, Ramos Hernández N. Manual de automonitoreo de la Asociación Latinoamericana de Diabetes (ALAD). Documentos selectos de posición y consenso de ALAD. [Document on Internet]. [Cited 8 Feb 2019]. Available from: http://www.a la da merica la tina.org/wpcontent/uploads/2016/10/AUTOMO NITOREO-PARA-DIABETES.pdf

35. Pisano González MM, González Pisano A. La modifica ción de los hábitos y la adherencia terapéutica, clave para el controlde la enfermedad crónica. Enferm. Clin. 2014; 24(1): 59-66.
36. Glasgow RE, Toobert DJ, Barrera M Jr, Stryker LA. Assessment of problem solving: a key to successful diabetes self-management. J. Behav. Med. 2004; 27(5): 477-490.

37. Fisher EB, Thorpe CT, Devellis BM, Devellis RF. Healthy coping, negative emotions, and diabetes management: A systematic review and appraisal. Diabetes Educ. 2007; 33(6): 1080-1103.

38. American Diabetes Association. Lifestyle Management: Standards of Medical Care in Diabetes - 2019. Diabetes Care. 2019; 42(supl 1): S46S60

39. Galindo Rubio M, Jansa Morató M, Menéndez Torre E. Therapeutic education and self-care: Results from the cross-sectional study Diabetes, Attitudes, Wishes and Needs 2 (DAWN2) in Spain. Endocrinol. Nutr. 2015; 62(8): 391-399.

40. Tricco AC, Ivers NM, Grimshaw JM, Moher D, Turner L, Galipeau J, et al. Effectiveness of quality improvement strategies en the management of diabetes: a systematic review and meta-analysis. Lancet. 2012;379(9833): 2252-2261.

41. Norris SL, Engelgau MM, Narayan KM. Effectiveness of selfmanagement training in type 2 diabetes: A systemic review of randomized controlled trials. Diabetes Care. 2001; 24(3): 561-587.

42. Compeán Ortiz LG, Gallegos Cabriales EC, González González JG, Gómez Meza MV. Conductas de autocuidado e indicadores de salud en adultos con diabetes tipo 2. Rev. Latino-Am. Enferma gem. 2010; 18(4): 17 .

43. Abbate SL. Changing systems, changing lives: Improving the quality of diabetes care. Diabetes Spectr. 2004; 17(2): 89-90.

44. Consejo Nacional de Educadores en Diabetes A.C. Misión y visión. CONED. [Document on Internet]. 2014. [Updated 2019; cited 14 Feb 2019]. Available from: http://www.coned.org.mx/indexclaf.html?option=com_content\&view=ar ticle $\&$ id $=84 \&$ Itemid $=1317$ 